\title{
POTENSI INFUSA DAUN OKRA (Abelmoschus esculentus $L$. Moench) TERHADAP PENURUNAN KADAR GLUKOSA DARAH MENCIT-INDUKSI ALOKSAN
}

\author{
THE POTENTIAL INFUSION OF OKRA LEAVES \\ (Abelmoschus esculentus L. Moench) IN ALLOXAN-INDUCED \\ DIABETIC MICE
}

\author{
Eva Nor Diana Lestari ${ }^{1}$, Rahmat A Hi Wahid ${ }^{2 *}$, Nurul Marfu'ah ${ }^{1}$ \\ Program Studi Farmasi, Fakultas Ilmu Kesehatan, Universitas Darussalam Gontor ${ }^{1}$ \\ Program Sarjana Farmasi, Fakultas Sains dan Teknologi, Universitas PGRI Yogyakarta ${ }^{2}$ \\ *Penulis korespondensi,e-mail: rahmat@upy.ac.id
}

\begin{abstract}
ABSTRAK
Diabetes melitus (DM) merupakan suatu penyakit yang ditandai dengan tingginya kadar glukosa dalam darah. Kandungan kimia pada tanaman okra di antaranya $67,50 \% \alpha-$ selulosa, 15,40\% hemiselulosa dan flavonoid yang berefek antidiabetes. Tujuan penelitian untuk mengetahui potensi infusa daun okra terhadap penurunan kadar glukosa darah mencit (Mus musculus) yang diinduksi aloksan. Metode penelitian yang digunakan adalah eksperimental dengan desain Rancangan Acak Lengkap (RAL). Penelitian ini menggunakan 20 ekor mencit jantan berusia tiga bulan yang diinduksi diabetes menggunakan aloksan dan dibagi ke dalam lima kelompok. (1) Kelompok kontrol negatif, diberi aquades, (2) Kelompok kontrol positif, diberi glibenklamide dosis $3 \mathrm{mg} / \mathrm{KgBB}$, dan kelompok (3-5) diberi infusa daun okra dengan dosis 0,2, 0,4, dan 0,6 $\mathrm{mL} /$ hari selama 14 hari. Pengukuran kadar glukosa dilakukan setelah 14 hari perlakuan menggunakan glukometer (Easy Touch ${ }^{\circledR} G C U$ ). Analisis data menggunakan uji One Way ANOVA dengan tingkat signifikansi $95 \%(p=0,05)$. Hasil penelitian menunjukkan infusa daun okra dosis $0,2,0,4$, dan $0,6 \mathrm{~mL} /$ hari menurunkan kadar glukosa darah namun tidak bermakna secara statistik $p=0,990 \quad(p>0,05)$. Hasil penelitian dapat disimpulkan bahwa pemberian infusa daun okra dosis 0,2, 0,4, dan 0,6 mL/hari berpotensi menurunkan kadar glukosa darah mencit terinduksi aloksan tetapi tidak signifikan.
\end{abstract}

Kata kunci: Aloksan, daun okra, glukosa darah, infusa, mencit

\section{ABSTRACT}

Diabetes mellitus (DM) is a disease that characterized by high levels of glucose in the blood. The chemical contents of okra plant are $67.50 \% \quad \alpha$-cellulose, $15.40 \%$ hemicellulose and flavonoids containing antidiabetic effects. The study aimed to determine the potential of okra leaves infusion to reducing blood levels of mice (Mus musculus) that was induced by alloxan. The study was an experimental study with Completely Randomized Design (CRD). 20 male mice aged three months was induced by alloxan and divided into five groups. (1) Negative control, treated with aquades, (2) Positive control, treated with glibenclamide $3 \mathrm{mg} / \mathrm{kgBW}$, and Group (3-5) treated with okra leaves infusion doses of $0.2,0.4$, and $0.6 \mathrm{~mL} /$ day for 14 days. Glucose levels were 
measured after 14 days of enzymatic treatment using a glucometer (Easy Touch ${ }^{\circledR}$ GCU). Data was analyzed using One Way ANOVA with significant level 95\% ( $p<0,05)$. The results showed that okra leaves infusion doses of 0.2, 0.4 , and $0.6 \mathrm{~mL} /$ day reduced blood glucose levels but did no significant statistics $p=0,990(p>0,05)$. In conclusion, that administration of okra leves infusion doses of $0.2,0.4$, and $0.6 \mathrm{~mL} /$ day has potential to reducing of blood glucose levels in the mice induced by alloxan although there is no significant statistics.

Keywords: Alloxan, blood glucose, infusion, mice, okra leaves.

\section{PENDAHULUAN}

Diabetes melitus (DM) merupakan suatu penyakit yang ditandai dengan tingginya kadar glukosa dalam darah akibat terganggunya fungsi insulin yang tidak diproduksi kembali (T.Dipiro et al., 2015). Data dari (Federation, 2019) menyebutkan bahwa pada tahun 2019 Indonesia menempati peringkat ke-7 dunia dengan prevalensi penderita DM tertinggi di dunia bersamaan dengan negara China, India, Amerika Serikat, Pakistan, Brazil, dan Meksiko dengan jumlah estimasi sekitar 10,7 juta orang. Tahun 2030 diperkirakan prevalensi DM sebagai salah satu penyebab utama kematian di dunia. Di Indonesia diperkirakan pada tahun 2030 akan memiliki penderita DM sebanyak 13,7 juta orang (Federation, 2019). Data hasil Riskesdas 2018 menunjukkan prevalensi DM berdasarkan diagnosis sebesar 1,5\% (Kemenkes, 2019).

Indonesia merupakan salah satu negara maju yang mempunyai banyak kekayaan alam. Sebagian besar kekayaan alam sudah dimanfaatkan untuk berbagai penyembuhan penyakit. Salah satunya adalah tanaman okra. Okra sangat terkenal di masyarakat Asia termasuk Indonesia sebagai sayur dan berkhasiat obat (Khomsug et al., 2010). Di Asia dan Indonesia, okra biasanya digunakan secara empiris sebagai sayur untuk mengobati iritasi lambung. Selain itu juga digunakan untuk mengobati penyakit bisul, radang paruparu, sakit tenggorokan, diabetes mellitus dan hiperlipidemia (Sabitha et al., 2011).

Beberapa penelitian tentang tanaman okra telah dilakukan oleh (Safitri, 2015). menunjukkan bahwa ekstrak etanol buah okra dapat menurunkan kadar glukosa darah. Penelitian Desthia melaporkan bahwa ekstrak etanol daun okra dapat menurunkan kadar glukosa darah (Desthia et al., 2015). Siti juga menyebutkan bahwa infus buah okra juga dapat menurunkan kadar glukosa darah (Siti, 2017). Delviana membuktikan melalui penelitiannya bahwa simplisia daun okra memiliki senyawa antioksidan yaitu flavonoid yang berefek sebagai antidiabetes (Delviana, 2017). Jain dkk menyebutkan kandungan kimia yang terdapat pada okra diantaranya $67,50 \% \alpha$-selulosa dan $15,40 \%$ hemiselulosa, 
dimana kandungan kimia $\alpha$-selulosa dan hemiselulosa tersebut memiliki efek antidiabetes (Jain et al., 2012).

Pada penelitian ini akan dilakukan uji potensi infusa daun okra (Abelmoschus esculentus L. Moench) terhadap penurunan kadar glukosa darah mencit yang diinduksi aloksan. Penelitian oleh Siti bahwa pemberian air infusa buah okra dosis $6 \mathrm{~mL} 2 \mathrm{x}$ sehari selama 30 hari berpengaruh menurunkan kadar gula darah tikus putih hiperglikemia (Siti, 2017). Sediaan infusa digunakan pada penelitian ini didasarkan pada penggunaan empiris di masyarakat dalam mengobati diabetes mellitus yaitu dengan cara direbus. Dimana prinsip penyarian dengan infusa hampir sama dengan penggunaan di masyarakat dengan cara merebus. Penggunaan metode infusa juga menggunakan peralatan yang sangat sederhana, mudah dipakai dan dapat menyaring simplisia dengan pelarut air dalam waktu yang singkat (Wijayanti, 2008). Pada penelitian ini diharapkan mampu membuktikan kemanfaatan daun okra sebagai antidiabetes yang potensial.

\section{METODE PENELITIAN}

\section{Alat dan Bahan}

Alat-alat gelas yang lazim digunakan (Pyrex), batang pengaduk, kompor listrik, thermometer, neraca analitik $\left(\right.$ Fujitsu $^{\circledR}$ ), jarum suntik (Onemed), jarum sonde (force feeding needle), kandang mencit, pinset, gunting dan glukometer dan glukosa strip (Easy Touch $\left.{ }^{\circledR} G C U\right)$.

Bahan yang digunakan adalah daun okra merah yang berasal dari daerah Desa Suboh, Kabupaten Situbondo dan dipetik pada sekitar pukul 10.00-12.00 WIB, aquades, aloksan, CMC-Na 0,5\%, dan $\mathrm{NaCl} 0,9 \%$.

\section{Jalannya Penelitian}

Pembuatan Infusa Daun Okra

Pembuatan ekstrak dilakukan dengan metode infundasi. Daun okra dicuci dan disortasi agar memisahkan bagian daun yang rusak, lalu dikeringkan menggunakan bantuan sinar matahari dan ditutup kain hitam. Daun kering okra diiris kecil-kecil selanjutnya ditimbang dengan berat masing-masing $10 \mathrm{mg}, 20 \mathrm{mg}$ dan $30 \mathrm{mg}$ lalu direbus dengan dalam $100 \mathrm{~mL}$ air yang telah mendidih selama 15 menit. Setelah direbus kemudian airnya disaring dan didinginkan untuk menghilangkan ampas daun okra. 
Pembuatan Larutan Aloksan

Mencit dibuat diabetes dengan menginjeksikan aloksan secara intraperitonial (Karau et al., 2012). Dosis aloksan yang diberikan pada mencit yaitu sebanyak 150 mg/Kg BB secara intraperitoneal (Katiyar et al., 2011). Setelah pemberian aloksan maka di hari ke-4 dilakukan pengukuran kadar glukosa darah mencit (Putri, 2012). Kadar glukosa darah mencit jantan normal yaitu sekitar 71-124 mg/dL. Menurut penelitian Lestari (2015) bahwa mencit dengan kadar glukosa darah yang lebih besar dari 124 $\mathrm{mg} / \mathrm{dL}$ dapat digunakan untuk perlakuan selanjutnya, karena mencit tersebut sudah bisa dikatakan diabetes.

Pembuatan Larutan Glibenklamid

Dosis glibenklamid yang diberikan pada mencit adalah $3 \mathrm{mg} / \mathrm{Kg}$ BB mencit $(0,06$ $\mathrm{mg} / 20 \mathrm{~g}$ BB mencit). Untuk membuat $25 \mathrm{~mL}$ sediaan suspensi yaitu dengan menyiapkan glibenklamid 0,06 mg/0,2 mL dalam CMC-Na 0,5\% maka dibutuhkan sebanyak 0,06 mg/0,2 mL x $25 \mathrm{~mL}$ sehingga hasilnya sebanyak 7,5 mg glibenklamid dalam $25 \mathrm{~mL}$ larutan CMC-Na 0,5\%. Cara pembuatan larutan suspensi glibenklamid yaitu dengan menimbang glibenklamid sebanyak 7,5 mg, kemudian ditimbang CMC-Na $125 \mathrm{mg}$, lalu didispersikan ke dalam aquades $2,5 \mathrm{~mL}$ dan diamkan selama 15 menit, diaduk hingga homogen. Setelah homogen, lalu dipindahkan ke dalam labu ukur $25 \mathrm{~mL}$ dan ditera volumenya hingga mencapai tanda dengan menambahkan sedikit demi sedikit aquades.

Pemberian Infusa Daun Okra

Pemberian infusa daun okra pada mencit dilakukan secara oral dengan menggunakan alat sonde. Pemberian dilakukan sekali sehari pada waktu pagi selama 14 hari, kemudian dilakukan pengukuran kadar glukosa darah pada mencit.

\section{Proses Perlakuan}

Penelitian ini telah mendapatkan persetujuan etik (ethical clearance) dari komite etik penelitian kesehatan Fakultas Kedokteran Universitas Muhammadiyah Surakarta dengan nomor surat kelaiakan etik penelitian : 1876/A.1/KEPK-FKUMS/I/2019. 
Hewan uji yang digunakan dalam penelitian ini adalah mencit putih jantan galur Balb-C dengan berat badan rata-rata 20-29 gram dan berumur 2-3 bulan. Hewan uji ini diperoleh dari laboratorium hewan uji dan peternakan Universitas Muhammadiyah Yogyakarta.

Penelitian ini merupakan penelitian eksperimental secara in vivo dengan desain rancangan acak lengkap (RAL). Mencit dibagi menjadi 5 kelompok, yaitu sebagai kontrol negatif, positif dan perlakuan (P1,P2, dan P3). Masing-masing kelompok terdiri dari 4 ekor mencit. Pada kontrol negatif, mencit diinduksi aquades. Kontrol positif, mencit akan diberikan glibenklamid $3 \mathrm{mg} / \mathrm{Kg}$ BB. Sedangkan untuk kelompok perlakuan 1,2 dan 3 masing-masing diberikan infusa daun okra dosis 0,2 mL/hari, 0,4 $\mathrm{mL} /$ hari, dan 0,6 $\mathrm{mL} /$ hari selama 14 hari setiap pagi hari. Sebelum mendapatkan perlakuan mencit dibuat diabetes dengan menginjeksikan aloksan dosis $150 \mathrm{mg} / \mathrm{Kg} \mathrm{BB}$ secara intraperitoneal (Katiyar et al., 2011). Selama induksi dengan aloksan mencit tetap diberi makan dan minum. Mencit diobservasi selama 3 hari kemudian diperiksa kadar glukosa darahnya mengunakan glukometer kit. Mencit dikatakan hiperglikemia jika kadar glukosa darah >124 mg/dL (Lestari, 2015).

\section{Analisis Data}

Data hasil pengukuran kadar glukosa darah dianalisis menggunakan uji One-Way ANOVA dilanjutkan dengan uji beda rerata Post Hoc LSD dengan $\alpha=0,05$ menggunakan SPSS versi 16.0.

\section{HASIL DAN PEMBAHASAN}

Potensi Infusa Daun Okra terhadap Penurunan Kadar Glukosa Darah Mencit yang diinduksi Aloksan

Hasil dari penelitian pada potensi infusa daun okra (Abelmoschus esculentus L. Moench) terhadap penurunan kadar glukosa darah mencit yang diinduksi aloksan diperoleh hasil seperti yang ditunjukkan pada Tabel I. 
Tabel I. Rerata kadar glukosa darah sebelum dan sesudah perlakuan

Nama

Kadar Glukosa Darah (mg/dL)

Perlakuan

\begin{tabular}{cccc}
\hline & N & Sebelum Perlakuan X \pm SD & Setelah Perlakuan X \pm SD \\
\hline KN & 4 & $175 \pm 21,8$ & $130,5 \pm 66$ \\
KP & 4 & $165 \pm 27,1$ & $115,7 \pm 11,6$ \\
P1 & 4 & $179,2 \pm 25,7$ & $119,5 \pm 16,6$ \\
P2 & 4 & $226,7 \pm 121,9$ & $187,2 \pm 90,8$ \\
P3 & 4 & $218 \pm 66,9$ & $179,2 \pm 113,7$ \\
\hline
\end{tabular}

Keterangan : Kontrol Negatif (KN), Kontrol Positif (KP), Perlakuan 1 (P1), Perlakuan 2 (P2), Perlakuan 3 (P3), Standar Deviasi (SD). Hasil uji statistik ANOVA: $p=0,990(p>0,05)$.

Setelah pemberian aloksan menunjukkan adanya peningkatan Kadar Glukosa Darah (KGD) di atas kadar normal mencit pada umumnya (ditunjukkan pada hasil tabel sebelum perlakuan). KGD normal mencit menurut (Lestari, 2015) 71-124 mg/dL, dalam hal ini dapat diartikan bahwa kadar glukosa yang melebihi batas rentang normal maka mencit tersebut dapat dikatakan diabetes mellitus. Terjadinya peningkatan KGD mencit disebabkan oleh pengaruh pemberian senyawa diabetogen aloksan.

Tabel I menunjukkan bahwa tidak ada perbedaan yang nyata secara statistik antara kelompok kontrol positif, negatif dan kelompok perlakuan variasi dosis infusa daun okra $p=0,990(p>0,05)$. Namun terjadi penurunan kadar glukosa darah pada kelompok perlakuan 1,2 dan 3. Tabel tersebut memperlihatkan bahwa infusa daun okra memiliki aktivitas yang sama dengan kelompok kontrol positif yang mengandung glibenklamid.

Hasil penelitian ini tidak sejalan dengan penelitian oleh (Zaenab, 2018) bahwa pemberian air infus buah okra dengan dosis $6 \mathrm{~mL} / \mathrm{hari} 2$ kali sehari selama 30 hari dapat berpengaruh terhadap penurunan kadar gula darah tikus putih hiperglikemia. Kontras dengan ini, (Aditama, 2019) membuktikan melalui uji in vivo (mencit) bahwa ekstrak etanol 96\% daun okra dapat menurunkan kadar glukosa darah selama 14 hari $(p<0,05)$. Hasil yang berbeda dengan penelitian ini mungkin berkaitan dengan dosis yang rendah dan durasi terapi yang relatif singkat.

(Anjani and Rimbawan, 2018) berpendapat bahwa efektivitas okra dalam kaitannya dengan antidiabetes disebabkan adanya kandungan senyawa flavonoid yang memiliki aktivitas antioksidan yang berperan sebagai free radical scavenger. Kuersetin adalah flavonoid utama pada okra yang memiliki potensi antidiabetes melalui 
mekanisme meningkatkan uptake glukosa di jaringan, meningkatkan sensitivitas insulin, mencegah peroksidasi lipid, proliferasi sel hati dan pankreas, dan inhibitor $\alpha$ glukosidase.

Infusa Daun Okra yang Berpotensi terhadap Penurunan Kadar Glukosa Darah Mencit yang diinduksi Aloksan

Hasil dari penelitian pada potensi infusa daun okra (Abelmoschus esculentus L. Moench) terhadap penurunan kadar glukosa darah mencit yang diinduksi aloksan diperoleh selisih hasil kadar glukosa darah sebelum dan sesudah perlakuan seperti pada Tabel II. Pada Tabel II nampak pemberian infusa daun okra tampak tidak memberikan efek yang berbeda dalam menurunkan kadar glukosa darah mencit.

\begin{tabular}{|c|c|c|c|c|}
\hline \multirow{2}{*}{$\begin{array}{c}\text { Nama } \\
\text { Perlakuan }\end{array}$} & \multirow[b]{2}{*}{$\mathbf{N}$} & \multicolumn{2}{|c|}{ Kadar Glukosa Darah (mg/dL) } & \multirow[b]{2}{*}{ Selisih } \\
\hline & & $\begin{array}{c}\text { Sebelum } \\
\text { Perlakuan } \mathrm{X} \pm \text { SD }\end{array}$ & $\begin{array}{c}\text { Setelah } \\
\text { Perlakuan } \mathrm{X} \pm \text { SD }\end{array}$ & \\
\hline K- & 4 & $175 \pm 21,8$ & $130,5 \pm 66$ & $-44,5 \pm 52,8^{\mathrm{a}}$ \\
\hline $\mathbf{K}+$ & 4 & $165 \pm 27,1$ & $115,7 \pm 11,6$ & $-49,7 \pm 21,3^{\mathrm{a}}$ \\
\hline P1 & 4 & $179,2 \pm 25,7$ & $119,5 \pm 16,6$ & $-59,7 \pm 25,5^{\mathrm{a}}$ \\
\hline $\mathbf{P 2}$ & 4 & $226,7 \pm 121,9$ & $187,2 \pm 90,8$ & $-39,5 \pm 67,1^{\mathrm{a}}$ \\
\hline P3 & 4 & $218 \pm 66,9$ & $179,2 \pm 113,7$ & $-38,7 \pm 114^{\mathrm{a}}$ \\
\hline
\end{tabular}

Keterangan : Perlakuan 1 (P1), Perlakuan 2 (P2), Perlakuan 3 (P3), Terjadi Penurunan Kadar Glukosa (-), Tidak Signifikan $\left(^{\mathrm{a}}\right)$

Salah satu pola penyembuhan DM yaitu dengan mengkonsumsi makanan yang mengandung polisakarida larut air (PLA) dan kandungan serat pangan yang tinggi. Mengkonsumsi PLA akan menyebabkan menurunnya efisiensi penyerapan karbohidrat. Penurunan tersebut dapat meringankan kinerja pankreas sehingga dapat memperbaiki fungsinya dalam menghasilkan insulin. Selain itu serat makanan yang tinggi juga dapat menyebabkan penyerapan glukosa pada usus mengalami perlambatan karena serat mampu menurunkan absorbsi glukosa (Permatasari, 2008).

Penelitian oleh (Li et al., 2019) bahwa pemberian okra polisakarida dosis 200 atau $400 \mathrm{mg} / \mathrm{KgBB}$ tikus selama 8 minggu mampu mengobati Diabetes mellitus type-2 tikus melalui aktivasi phosphoinositidee 3-kinase (PI3K) / protein kinase B (AKT) / glycogen synthase kinase 3 beta (GSK3 $\beta$ ), dan meningkatkan ekspresi gen nuclear factor 
erythroid-2 related factor-2 (Nrf2) sehingga mempromosikan ekspresi heme oxygenase1 (HO-1) dan Superoxyde dismutase-2 (SOD2). Dimana ini semua adalah gen-gen antioksidan, respon imun dan respon inflamasi yang bertanggungjawab terhadap perlindungan sel $\beta$ dari kerusakan dan mencegah timbulnya diabetes mellitus pada hiperglikemia ( Bhakkiyalakshmi, 2015).

Serat tersusun dari karbohidrat komplek yang tahan terhadap proses pencernaan dan penyerapan di usus halus serta mengalami fermentasi sebagian atau keseluruhan di usus besar. Konsumsi serat sesuai dengan kebutuhan dapat menimbulkan rasa kenyang akibat masuknya karbohidrat komplek yang menyebabkan menurunnya selera makan dan akhirnya akan menurunkan konsumsi makan. Serat juga mengandung kalori rendah yang dapat menurunkan kadar glukosa darah dan lemak dalam tubuh (Stark et al., 1994; Southgate, 1995; Posted, 2002).

Mekanisme serat dalam menurunkan kadar glukosa dalam darah yaitu saat serat masuk kedalam tubuh, serat tidak dicerna dan diserap didalam usus halus, maka bagian serat yang tidak tercerna akan menuju ke usus besar. Hal ini menyebabkan makanan berserat cenderung tidak dapat menyebabkan kenaikan kadar glukosa darah karena menghambat proses penyerapan dalam usus halus. Meningkatnya konsumsi serat menguntungkan karbohidrat penyebab diabetes terutama gula-gula sederhana karena dapat memperlambat gerak laju gula dari lambung ke usus kecil sehingga melawan peningkatan konsentrasi gula darah cepat setelah mengkonsumsi gula (Heilbronn et al., 2002). Mekanisme serat yang tinggi dapat memperbaiki kadar gula darah dengan kecepatan penyerapan makanan (karbohidrat) masuk ke dalam aliran darah yang dikenal dengan glycemic index (GI) (Harland and Oberleas, 2001).

Senyawa lain yang diduga dapat menurunkan kadar glukosa darah yaitu senyawa antioksidan dengan adanya senyawa flavonoid didalamnya. Menurut penelitian (Delviana, 2017) bahwa skrinning fitokimia dari simplisia daun okra menunjukkan adanya senyawa yang berpotensi sebagai antioksidan yaitu flavonoid. Efek penurunan kadar glukosa disebabkan adanya kandungan flavonoid pada daun okra. Kandungan flavonoid dapat menurunkan KGD dengan kemampuannya sebagai zat antioksidan. Flavonoid bersifat protektif terhadap kerusakan sel $\beta$ sebagai penghasil insulin serta dapat meningkatkan sensitifitas insulin. Mekanisme lain dari flavonoid adalah menghambat GLUT-2 mukosa usus sehingga dapat menurunkan absorpsi glukosa. 
Selain itu, flavonoid juga dapat menghambat fosfodies terasi, dimana hal ini dapat menyebabkan sekresi insulin oleh sel $\beta$ pankreas (Dharmayudha and Anthara, 2013).

\section{Berat Badan Mencit setelah pemberian Infusa Daun Okra}

Hasil penelitian potensi infusa daun okra (Abelmoschus esculentus L. Moench) terhadap penurunan kadar glukosa darah mencit yang diinduksi aloksan diperoleh selisih rerata berat badan mencit terlihat Tabel III.

Tabel III. Rerata berat badan mencit antara kelompok perlakuan

\begin{tabular}{llc}
\hline Kelompok & N & Rerata BB mencit (g) X \pm SD \\
\hline KN & 4 & $28,75 \pm 2,87$ \\
KP & 4 & $28,50 \pm 2,38$ \\
P1 & 4 & $26,75 \pm 3,59$ \\
P2 & 4 & $25,75 \pm 2,87$ \\
P3 & 4 & $26,95 \pm 3,03$ \\
\hline
\end{tabular}

Tabel III menunjukkan bahwa rerata berat badan mencit memiliki perbedaan setelah dilakukannya infusa daun okra selama 14 hari. Berat badan mencit pada kelompok negatif menunjukkan nilai paling tinggi dibandingkan dengan kelompok positif, P1, P2, dan P3. Rerata berat badan mencit kelompok P1, P2, dan P3 menunjukkan bahwa terjadi penurunan berat badan mencit dibandingkan dengan kelompok negatif dan kelompok positif. Berdasarkan hasil dari uji One Way ANOVA menunjukkan $p=0,333(p>0,05)$ yang artinya bahwa tidak ada perbedaan secara signifikan. Hal ini menunjukkan bahwa daun okra cenderung tidak meningkatkan berat badan mencit dalam kondisi DM.

\section{KESIMPULAN}

Simpulan dari penelitian ini yaitu infusa daun okra tidak berpotensi terhadap penurunan kadar glukosa darah mencit yang diinduksi aloksan. Meskipun demikian, kelompok P1 dengan konsentrasi infusa daun okra $20 \%$ dengan dosis 0,2 mL menunjukkan hasil penurunan kadar glukosa darah paling tinggi dibandingkan dengan kelompok P2 dan kelompok P3. 


\section{UCAPAN TERIMAKASIH}

Penulis mengucapkan terima kasih kepada Kepala Program Studi Farmasi dan dosen pembimbing Universitas Darussalam Gontor yang telah memfasilitasi dan berkontribusi dalam pelaksanaan penelitian, serta beberapa pihak yang mendukung penelitian ini.

\section{DAFTAR PUSTAKA}

A, Strak., Z, Madar., \& Fibre, D. (1994). In: Goldberg, I (ed). Functional Foods: Designer Foods, Pharmafoods, and Nutraceuticals. Chapman \& Hall. New York.

Aditama. (2019). Antidiabetic activities of $96 \%$ ethanol extract of abelmoschus esculentus on Balb-c Mice Strain. Farmasains, 4(2), 21-25.

Anjani, P. P. D., \& Rimbawan, E. (2018). Potensi antidiabetes ekstrak okra ungu (Abelmoschus esculentus L.) pada tikus model diabetes yang diinduksi Streptozotosin. Insitut Pertanian Bogor.

DAT, Southgate. (1995). ietary fibre analysis. norwich : the royal society of chemistry.

Delviana. (2017). Aktivitas antioksidan dari ekstrak etanol daun Okra (Abelmoschus esculentus Moench. Skirpsi. Universitas Sumatera Utara, Medan.

Desthia, U., Mita, Yuniarni, Umi, Choesrina, \& Ratu. (2015). Uji Aktivitas Hipoglikemik Ekstrak Etanol Daun Okra (Abelmoschus esculentus (L). Moench) Pada Mencit Jantan Galur Swiss Webster Dengan Metode Toleransi Glukosa Oral. Prosiding Penelitian SpeSIA.

Dharmayudha, A. A. G. O., \& Anthara, M. S. (2013). Identifikasi golongan senyawa kimia dan pengaruh ekstrak etanol buah naga daging putih (Hlocereus undatus) terhadap penurunan kadar glukosa darah serta bobot berat badan tikus putih jantan (Rattus norvegicus) yang diinduksi aloksan. Buletin Veternier Undayana, 5(1), 3140 .

Dornadula, B., Ramkumar, \& Mohanram, E. S. P. R. R. P. K. (2015). The emerging role of redox-sensitive Nrf2-Keap1 pathway in diabetes. Pharmacol Research, 91, 104114.

Federation, I. diabetes. (2019). International diabetes federation diabetes atlas 9th edition. International Diabetes Federation.

GJ, Posted. (2002). Makalah Falsafah Sains. Institut Pertanian Bogor.

Harland, B. F., \& Oberleas, D. (2001). Effect of dietary fiber and phytate on the homeostasis and biovaibility of minerals. Boca Raton : CRC Press. 
Heilbronn, L. K., Noakes, M., \& Clifton, P. M. (2002). The effect of high and low glycemic index energy restricted diet on plasma lipid and glucose profile in type 2 diabetic subject with varying glycemic control. Journal American College of Nutrition, 21(2), 120-127.

Jain, N., Jain, R., Jain, V., \& Jain, S. (2012). A Review on : Abelmoschus esculentus. Pharmacia, 1(3), 84-89.

Karau, M. G., Njagi, E. N. M., Machocho, A., \& Wangai, L. N. (2012). Hypoglycemic activity of aqueous and Ethylacetate leaf and stem bark extracts of pappea capensis (L.) in alloxan induced diabetic BALB/c mice. British Journal of Pharmacology and Toxicology, 3(5), 251-258.

Katiyar, D., Singh, B., Lall, A., \& Haldar, C. (2011). Evaluation of antidiabetic and hypolipidemic activity of chitooligosaccharides in alloxan induced diabetes mellitus in mice. International Journal of Pharma and Bio Sciences, 2(1), 407416.

Kemenkes. (2019). Riset Kesehatan Dasar (Riskesdas) 2018. Kementerian Kesehatan Republik Indonesia.

Khomsug, P., Thongjaroe, W., Pakdeenaro, N., \& Suttajit, M.-. (2010). Antioxidative activities and phenolic content of extracts from Okra (Abelmoschus esculentus L.). Research Journal of Biological Sciences, 5(4), 310-313.

Lestari, N. W. (2015). Pengaruh ekstrak rimpang rumput teki (Cyperus rotundus L.) terhadap kadar gula darah pada mencit (Mus musculus L.) jantan. In Skirpsi. Universitas Lampung. Lampung.

Li, Z., Zhang, J., Liu, B., Yan, T., Xu, F., Xiao, F., Wu, B., Bi, K., \& Ying Jia. (2019). Polysaccharide from Okra (Abelmoschus esculentus (L.) Moench) improves antioxidant capacity via PI3K/AKT pathways and Nrf2 translocation in a type 2 diabetes model. Molecules, 24(10), 1-17.

Permatasari, A. A. (2008). Uji efek penurunan kadar glukosa darah ekstrak etanol 70\% buah jambu biji pada kelinci jantan lokal. In Skripsi. Fakultas Farmasi, Universitas Muhammadiyah Surakarta.

Putri, O. B. (2012). Pengaruh pemberian ekstrak buah labu siam (Sechium edule) terhadap penurunan kadar glukosa darah tikus wistas yang diinduksi aloksan. In Skripsi. Fakultas Kedokteran, Universitas Diponegoro.

Sabitha, V., Ramachandran, S., Naveen, K. R., \& Panneerselvam, K. (2011). Antidiabetic and antihyperlipidemic potential of abelmoschus esculentus (L.) Moench. in Streptozotocin-Induced diabetic Rats. Journal of Pharmacy and Bioallied Scienced, 3(3), 397-402.

Safitri, N. (2015). Uji potensi antidiabetes ekstrak etanol buah okra (Albelmoschus 
Esculentus L) pada mencit putih jantan (Mus Musculus) yang diinduksi glukosa. Skirpsi. Universitas Alauddin Makassar.

Siti, Z. (2017). Penggunaan berbagai dosis infus buah okra (Abelmoschus esculentus) untuk penurunan kadar gula darah tikus putih (Rattus norvegicus) hiperglikemia. Jurnal Seminar Nasional Dan Gelar Produk.

T.Dipiro, J., Tarbert, R. L., Yee, G. C., Matzke, G. R., Wells, B. G., \& Michael Posey, L. (2015). Pharmacotherapy: A Patophysiologic Approach (9th Editio). Mc Graw Hill. New York. USA.

Wijayanti, A. W. (2008). Uji aktivitas mukolitik infusa daun pare (Momordica charantia L.) pada muskus usus sapi secara in vitro. In Skirpsi. Fakultas Farmasi, Universitas Muhammadiyah Surakarta.

Zaenab. (2018). Pengaruh pemberian air infus buad okra (Abelmoschus esculentus) dengan frekuensi yang berbeda terhadap kadar gula darah tikus putih (Rattus norvegicus) hiperglikemia. Prosiding Seminar Nasional IV 2018. 